\title{
Pricing for Natural Gas
}

\section{Valentyna Novosad}

Scientific Company "MAE", 33 Horyva st., Kyiv, Ukraine

\section{Email address:}

mae2010@meta.ua

\section{To cite this article:}

Valentyna Novosad. Pricing for Natural Gas. Journal of Energy and Natural Resources. Special Issue: Marketing in Energy Pricing. Vol. 5, No. 3-1, 2016, pp. 5-8. doi: 10.11648/j.jenr.s.2016050301.12

\begin{abstract}
In this article, I showed the existing problems in the pricing for natural gas and tried to explore the ways to overcome them. Market research of natural gas consumers can determine the conditions of natural gas supply acceptable for each consumer. Giving for consumers the choice from many different conditions of natural gas supplies and corresponding amendments to the basic price, you can solve many problems in the pricing of the natural gas.
\end{abstract}

Keywords: Economy, Marketing, Natural Gas Pricing, Natural Gas Market

\section{Introduction}

Natural gas is a valued source of energy because it is versatile and burns cleanly. As result natural gas is common place in applications including cooking, residential and commercial heating, industrial process feed stocks and electrical generations. [7] Currently, the share of natural gas in the global structure of energy consumption is about $24 \%$. According to the date of International Energy Agency the consumption of natural gas is expected to increase in the overall energy balance. [1]. Main factors contributing to the growth of natural gas consumption in the world are:

-growth of number of power stations that used the natural gas,

- decrease in attractiveness of nuclear energy and environmental problems.

Natural gas production in the United States has increase substantially due technological advancements in natural gas extraction methods [10].The United States have the largest amount of natural gas consumption. there are over 6300 producers of natural gas [2]. Over 530 natural gas processing plants are responsible for processing almost 15 trillion cubic feet of natural gas and extracting over 630 million barrels of natural gas liquids [2].

160 pipeline companies in the United States operate over 300000 miles of pipe.[2]. About 123 natural gas storage operations control approximately 400 underground storage facilities with storage capacity of 4059 billion cubic feet (Bcf) of natural gas and average daily deliverability of $85 \mathrm{Bcf}$ per day[2]. About 1200 natural gas distribution companies have 1,2 million miles of distribution pipe. Many of these companies maintain monopoly status in their distribution region. [2].

This huge natural gas industry requires special attention. The introduction of the market in this important industry creates competition among the companies that are part of a system for providing of consumers with natural gas.

At the same time with introduction of the natural gas market, a huge amount of new relationships between producers, processing plants, pipeline companies, storage operations, distribution companies and their consumers was created. Also a lot of the different natural gas prices appeared with the development of the natural gas market.

The use of main principles of marketing in researches of relationship in this industry, opportunities and needs of producers, processing plants, storage operations, pipeline companies, distribution companies and consumers will make the process of pricing in this industry beneficial to the whole society.

\section{Main Part}

Existing business relationships in the natural gas industry can be represented by the scheme as the stages of natural gas sale. (Fig.1)

At each stage, indicated on the scheme of business relationships in natural gas industry, there is a large amount of transactions, relationships, and, accordingly, a large amount of prices. The system of prices in this scheme is based on the needs and opportunities to maneuver of producers, marketers, LDC, and transporters.

However this scheme of business in natural gas industry is 
built in order to satisfy the needs of natural gas consumers. In the same time modern issues to improve the climate on the Earth and to keep useful fossil fuels impose some conditions on the consumption of natural gas by consumers.

So, we have two sides that play different roles in the process of natural gas pricing. On one side there are the companies that are involved in the process of ensuring with natural gas of end users. Their price level is based on the desire to cover the costs, to ensure the development of production and to receive a profit.

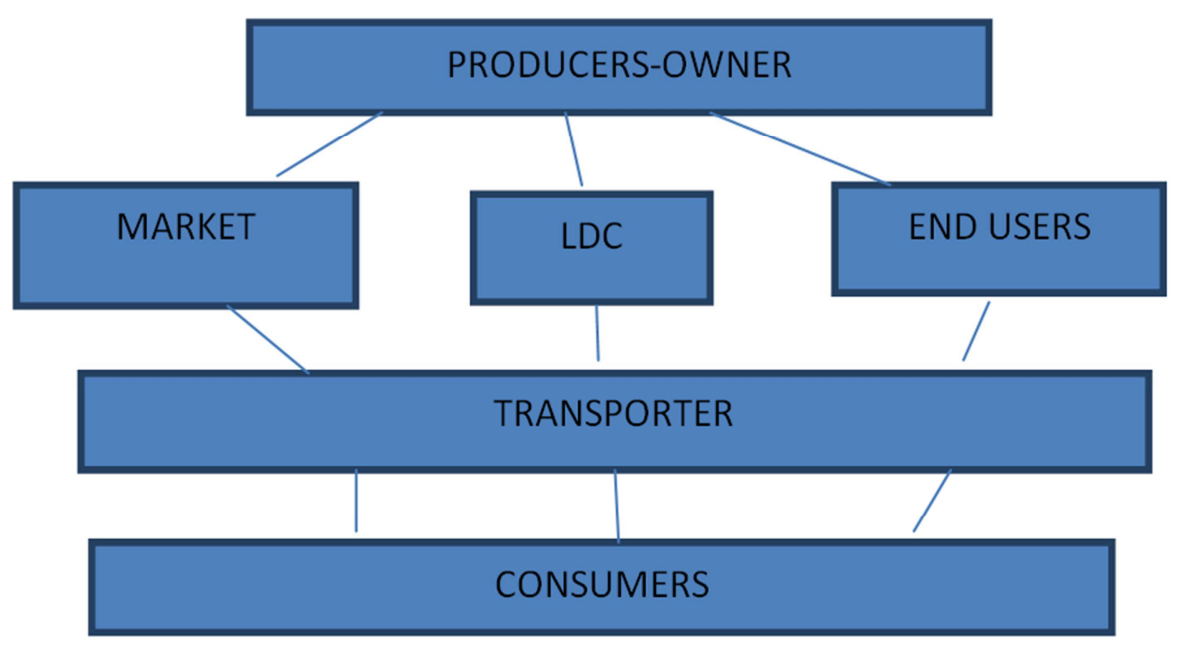

Fig. 1. Scheme of business relationships in natural gas industry.

On the other side are the consumers which want to have a price that corresponds to their abilities to pay accounts. The introduction of the natural gas market will adjust relationships between these two sides. Such markets of natural gas were established in North America and Europe.

The main principles on which is based their work are:

1). Ensuring a high level of protection of the rights and interests of consumers, and security of supply through diversification of sources of natural gas supply.

2 ). Free trade of natural gas and equality of the market subjects regardless of the state.

$3)$. Free choice of natural gas supplier.

4). Equality of rights to import and export of natural gas to other areas.

5). Non-interference of the state in the functioning of the natural gas market, except when it is necessary to ensure the common interests.

6). Ensuring equal rights to access to the gas transmission and gas distribution systems, and gas storages, and local distribution companies (LDC).

7) The inadmissibility of restriction on competition.

8). Compliance with the established norms and safety standards.

9). Protection of the environment and rational using of energy resources.

10). The responsibility of the market participants for violation of rules of the natural gas market and the terms of contracts $[8,9,10,11]$.

Active natural gas market naturally leads to lower prices for natural gas. However there are several economic drivers that provide an incentive for producers to continue producing even in conditions of declining prices:

1). If production from a natural gas well is halted; it may not be possible to restore the well's production due to reservoir and wellbore characteristics.

2 ). If net present value of production in the future may be negative relative to productions on the gas today, it may be better to produce gas today than to wait until the future to produce gas. If producer chooses not to operate a well, production can't be recovered the next month. In this time there are no guarantees that the prices for gas in the future are going to be higher than prices today.

3 ). Some natural gas is produced in association with oil, and in order to stop the flow of natural gas, the oil production must be stopped as well, which may be economic.

4). A producer may be financially or contractually bound to produce specific volumes of natural gas.

On the other hand an increase in prices for natural gas does not always correspond with financial opportunities of consumers'. However they are forced to accept the current price. Producers and consumers react rationally to changes in prices. Fluctuations in the price of the natural gas market provide the signals to both supplies and consumers to ensure a constant move towards supply and demand equally.

Considering that many factors can have a negative impact on the price fluctuations and on the financial conditions of the both producers and consumers, it is important to have knowledge about these factors. Because consumers are those for whom this process of production and transportation of natural gas is organized, it is necessary to research these consumers in terms of the basic principles of marketing.

Determination of the target consumers has been a major step in the marketing research. The large industrial enterprises are these target consumers. They prefer direct contracts with producers for a long period of delivery and more stable prices than on the market. Providing such opportunities for this category of consumers gives them to more stable operation and the ability to plan over the long 
time their activity.

The next large category of consumers includes power plants used natural gas as a fuel. Taking into account that the markets of electrical energy are in many countries and that prices for natural gas have significant effect on the price of electricity from these power plants, activity of both the natural gas and electricity markets should be organized in such way that their prices are accurate.

In United States in August, 19, 2014 there was a discussion about concept of the trading platform for natural gas [5]. At this meeting, the participants of the natural gas markets discussed about the time of the transactions on the markets. The meeting invited all interested parties to establish the rules of coordination of processes of interstate natural gas pipeline and public utilities. On April, 16, 2015 the Federal Energy Regularly Commission published these final Rules. [5].This document amended the current NAESBWGO standards [6]. The changes allow coordination of the actions of the both electricity and natural gas markets which are related by pricing system. However it's only in North America.

So, two major categories of consumers (the target consumers and power plants used natural gas as fuel) constitute a basic level of total consumption of natural gas.

Another important category of consumers consists of those consumers whose needs must be satisfied, regardless of fluctuations in natural gas production. They're called «protected consumers". This category of consumers includes:

- Domestic consumers.

- Enterprises and organizations that produce goods or provide services which are important for the whole society.

- Consumers which due to technical reasons can't change of suppliers.

Within this category of consumers there are a lot of consumers groups with different abilities to pay bills. The state may have regulate pricing of some groups of such consumers through the reducing of the payments of producers to the budget for the amount of natural gas supplied for these groups of consumers.

All other categories of consumers should work according with the general rules of the natural gas market.

Despite the fact that the price of natural gas for consumers is formed on the market, terms of delivery, quality of natural gas are different in different consumers. Therefore, the price of the natural gas market can be only as a base price for all consumer groups.

Given today's possibilities of computer calculations we can create a system of pricing for natural gas that will to able to take into account all conditions of the supply of natural gas for each consumer. It would be desirable that the provider could offer several forms of tariffs, conditions of supply and payments to stimulate the consumers to the rational use of natural gas.

The individual price for natural gas consumers can be formed on the base market price, taking into account such factors:

1. The quality of natural gas, which is supplied, it's physical and-chemical properties and other specifications.
2. Terms of the ensuring the safe supply of natural gas: for category C-minimum safety standards, for category Baverage safety standards, for category A -maximum safety standards.

3. Use technical means of measuring of the amount of consumed natural gas.

4. Conditions of the physical and commercial balancing.

5. Rules of distribution and regulation capacities in the critical moments of overloads.

6. Terms of the exchange of information.

7. The form and terms of payment for the consumed natural gas.

8. The type of tariff stimulating to the rational use of natural gas.

The use of such a large number of additions and amendments to the base natural gas price requires a detailed consideration of the conditions of supply of all consumers and the formation of small groups with the same conditions of natural gas supply.

Marketing research of natural gas consumers will allow to correctly determine the value of rebates and allowances to the price so that their using will have a stimulating role for the consumers and will bring benefit for suppliers. It is important that the provider will be to able to give for consumers opportunity to select the conditions that will be correspond with their needs and financial resources. In such circumstances, the consumer receives an additional opportunity to influence on the level of natural gas price, which is supplied for him personally.

\section{Conclusions}

The current pricing system for natural gas gives a good effect where there are the natural gas markets. At the same time, even in conditions of activity of the natural gas market there are conflicts of interests between suppliers and consumers. Such conflicts arise as a result of the equal prices for the supply of natural gas under different conditions. Such different conditions can be:

1. The quality of natural gas, which is supplied, its physical and-chemical properties and other specifications.

2 . Terms of the ensuring of security supply of natural gas.

3. Using technical means of measuring of the amount of consumed natural gas.

4. Conditions of the physical and commercial balancing.

5. Rules of distribution and regulation capacities in the critical moments of overloads.

6. Terms of the exchange of information.

7. The form and terms of payment for the consumed natural gas.

8. The type of tariff stimulating to rational use of natural gas.

Marketing research of consumers once every 3 years and establishment of the variety discount and bonuses for the market price will be to able taking into account all possible terms of delivery and settlement. The consumer receives an additional opportunity to influence on the level of the natural 
gas price, which is supplied for him personally. So, giving for consumers the choice from many different conditions of natural gas supplies and corresponding amendments to the basic price, you can solve many problems in the pricing of the natural gas.

\section{References}

[1] International Energy Agency http://www.iea.org/

[2] www.naturalgas.org/business/industry

[3] National Energy Marketin www.energymarketers.com

Association

[4] Natural Gas Market Reports www.reportlinker.com/Natural_Gas
[5] Federal Energy Regulatory Commission, http://www.ferc.gov/

[6] NAESBWGO standards, www.naesb.org

[7] Charles Augustin,Bob Broxson, Steven Peterson "Understanding Natural Gas Markers", Overview The North American Gas Marketplace", www.spectraenergy.com

[8] Natural Gas Market Law(Law on the Natural Gas Market and amending the Law on Electricity Market) LawN4646 Adoption Date 18.04.2001,ERRA

[9] www.erranet.org

[10] Overview about natural gas markets Www.api.org/oil-andnaturalgas-overview

[11] Regulation of natural gas companies.www.Law.cornell.edu/usecode/text15/chapter-158 